\title{
Living Labs, spaces for open innovation and technology transfer. An alternative to the solution of social problems in Paraguay
}

\author{
Antonieta Rojas De Arias ${ }^{1}$, Sergio Duarte Masi ${ }^{2}$, Diego Dorigo ${ }^{1}$, Francisco Arias Rojas ${ }^{1}$, \\ María Celeste Vega ${ }^{1}$, Miriam Rolon ${ }^{1}$ \\ ${ }^{1}$ Centro para el Desarrollo de la Investigación Científica, Pa'i Perez 265 e/ Mcal. Estigarribia, Asunción, Paraguay \\ ${ }^{2}$ Universidad Autónoma de Asunción (UAA). Jejuí N 667, Asunción, Paraguay
}

\section{Email address:}

rojasdearias@gmail.com (A. R. d. Arias), sedumapy@gmail.com (S. D. Masi), francisco2001@hotmail.com (F. A. Rojas)

\section{To cite this article:}

Antonieta Rojas De Arias, Sergio Duarte Masi, Diego Dorigo, Francisco Arias Rojas, María Celeste Vega, Miriam Rolon. Living Labs, Spaces for Open Innovation and Technology Transfer. An Alternative to the Solution of Social Problems in Paraguay. Social Sciences. Vol. 3, No. 3, 2014, pp. 74-79. doi: 10.11648/j.ss.20140303.12

\begin{abstract}
Living Labs model concentrate its effort to support actors, providing a neutral space in which stakeholders could know and co-develop innovations in real-world contexts and proposes five basic principles for the operations of the aforementioned living labs: courage, openness, realism, influence and sustainability. The objective of this paper is to propose and test a Living Lab and project management model from the actual stakeholders, following the perspective of the Stakeholder Theory and the Soft Systems Methodology (SSM). This perspective places the Research - Action model on the basis of the SSM model as an appropriate vehicle for the openness towards worldviews, problems and conflicts solving by the organizations, especially when it involves the formulation of possible cultural changes (structural, process, attitudinal) and "actions for improvement" are established. Therefore, we present the case of the Development Center for Scientific Research which brings together a multidisciplinary group of researchers and the project "Participatory approach with ethnic focus for Community Development of the Maskoy Diez Leguas ethnicity in the Central Chaco of Paraguay".
\end{abstract}

Keywords: Open Innovation, Technology Transfer, Education, Indigenous Communities, Vector Borne Diseases, Living Labs

\section{Introduction}

In most research forums, a central theme is always the transfer of results with special emphasis on action and the importance of integrating researchers to the real needs of the population [1]. This social demand, requesting that research with an impact in solving problems directly related to society and that works in the real world is made, has changed the original paradigm of performing only basic research, socalled by many of excellence (in the pursuit of truth ), by the one that- besides excellence - incorporates "relevance".

The change involves linking a research more closely to the relevant needs of the population and society in general (health, education, housing, infrastructure, etc.). It is clear that in that process, information and knowledge derived from scientific research must be transferred to all actors in a determined system or context. In fact, the problems associated with such transfer have become the focus and interest of the academic system, and moreover, have generated interface structures in universities, with different nomenclatures, whose mission is to transfer these results, but mainly towards productive and business sectors. In this sense, these questions are appropriate: Who will provide alternative solutions to the problems of society in less favored countries? How such transfer will comes into effect leading to social change and innovation?

New alternatives have arisen that have been positioned as novelties in innovation and social integration. The strongest alternative with bests results are the Living Labs [2].

A Living Lab is a model where all the stakeholders actively involved in a process of innovation, whether the State, civil society, social organization, academia and researchers, etc. interact in the form of an Innovation Lab either co-creating and/or validating the needs and solutions presented there through the use of Information and 
Communications Technology (ICT) as a means to it. In this regard, Ståhlbröst mentioned how the Living Labs have begun to grow rapidly throughout Europe [2].

These living laboratories concentrate their effort to support actors, providing a neutral space in which stakeholders could know and co-develop innovations in real-world contexts and proposes five basic principles for the operation of the aforementioned living laboratories: courage, openness, realism, influence and sustainability. This was complemented by the position of Katzy, Baltes and Gard [3] that says that Living Labs are spaces which can also reduce investment risks in the development of new products, as they work as "intermediaries" in the acceptance of the new by the users and customers.

In this sense, when speaking of a Living Lab we are referring to a methodological platform of $\mathrm{co}$ - creation and experimentation, in which the real actors are involved and where users and/or citizens participate amid environments also real, in order to obtain data for the Scientific and Technological Research, Development and Innovation that will be used in the specification, development, validation and/or improvement of products or complex solutions for these environments. What is sought with this, is to create a place where the users (or end users) and researchers could meet in the search of these solutions. The most commendable element of this method is the obtainment of results with immediate application, as methodologically, through this experimentation, data from the real world, i.e. from users and citizens, are obtained and not just theoretical projections obtained only from paper. In this sense, the more the citizens engage in different innovation processes, the more participatory and collaborative these processes will be.

There are four main services of Living Labs [4]: 1) Incubation of ideas and projects, 2) Conceptual design of products and services, 3) Prototyping and technical development, and finally, 4) Validation and scaling. Also, other activities that make up a Living Lab are: Co-creation, which refers to the co-design made between users and producers; Exploration, where the user is free to discover new uses and possibilities in what is explored; and Experimentation performed by the users in real world scenarios, and therefore, the final evaluation of the obtained results. Today, products for government entities, educational institutions, research centers, etc. are innovated and developed using this tool.

Working with citizens (we understand this as people who play a social life in a territory and at the same time may have a work facet in the case of persons with activity in this sense) is a challenge for the public administrations and in recent years it has also become an objective for the business area. Whether by searching marketing techniques (such as the focus group) or seeking innovative strategies such as the Lead-User Innovation and some others more focused on specific groups such as Open Innovation, the fact is that citizens (in user, employee or member of an association formats) are entering the innovation circuit companies and also want to take an active role in the social life of their community (we call this citizen empowerment) [5].

From its paradigm of seeking co-design and co-creation with stakeholders, Living Labs fit this model and allow everyone involved to find both a meeting place to develop these activities and the learning tools to create these innovation ecosystems, to which they provide four components:

- Public administration as a stakeholder in maintaining an innovation model that allows growth and economic development of the territory and, at the same time, getting close to the society by empowering it.

- Universities and centers of knowledge generation (foundations, institutes, technology transfer platforms) that could provide knowledge to find new uses and functions, while they add value to it.

- Private companies that could handle exogenous innovation models that seek new markets or new lines of business.

- Citizens who have personal and work concerns that could be met by developing innovative projects close to them.

A key and recurrent point is sustainability and it should be favored, i.e. the Living Labs should have financial support and a management model appropriate to outline a workable budget with the social conditions presented by the country, where the State ought to assume a leading and committed role to projects of this magnitude [6].

In a more specific context, it is important to note that Paraguay has an unequal growth environment for the population, since population increases while economic growth remains hindered. This translates into a fairly significant decrease in income, which also affects the ability to buy of Paraguayans, indexes that account for a high level of poverty, becoming one of the poorest countries in the region. The aforementioned accounts for the dire scene of poverty afflicting the country and is positioned as a major difficulty to bring about change in the most deprived population.

On the other hand, the country is also promoting and investing more and more in Science and Technology. Proof of this is the recent National Incentive Program for Researchers (PRONII in Spanish) implemented in 2011 that categorized the first 238 scientists of Paraguay and gave them a "financial reward" to continue doing science and producing knowledge. This is along the lines of Rutherford [7] which argues that the scientific community should be encouraged to do more to increase and improve the opportunities available for people to participate in the world of science. This requires at least two steps: i) to increase the number of scientists willing and able to communicate science and ii) to increase opportunities and incentives for people to be able to find science in rich humanistic environments in all fields of life.

Having said that, how do we link all this generated 
knowledge and that will continue being generated to solve the needs of the population, within an open innovation model?

The possible answer to this question is Living Labs, adapted to the Paraguayan context. As originally they are based on ICT, and in the particular case of Paraguay, their focus will be the social problems themselves -that is, the work with "vulnerable citizens" - and the strength is the interdisciplinarity, following the author Stichweh [8] and [9], which shows the current trend from internal differentiation in theories of scientific disciplines towards interdisciplinarity and finally to trans-disciplinarity. Thus, the complexity of science today requires new orders for knowledge, which tends to revolve around specific subjects and on the basis of descriptions that integrate diverse perspectives.

Indigenous families of Paraguay are considered social problems and vulnerable citizens that have a high degree of vulnerability, and if no solution is found for them, their vulnerability will increase vulnerability, following the lines of, which is exactly as the situation is presented in the country, "progressive vulnerability" [10].

The issue of indigenous peoples and families is well described in a work developed and presented within the United Nations that in its first chapter, already presents an alarming statement:

"being indigenous is being poor. Studies of the socioeconomic conditions of the indigenous people of Latin America show that being indigenous means being poor and that over time this situation has been perpetuated. Even though they have accumulated human capital (i.e. education or training opportunities), they could neither turn this into significantly greater gains nor reduce poverty that which differentiate them from the non-indigenous population" [11].

\section{Methodology}

The objective of this paper is to show, propose and test a project management model based on the actual stakeholders, following the Stakeholder Theory and the Soft Systems Methodology (SSM) according to Peter Checkland [12], which places Research-Action on the basis of the SSM model as an appropriate vehicle for openness to worldviews, problems and conflicts solving by the organizations, especially when the formulation of possible cultural changes (structural, process, attitudinal) are involved and "actions for improvement" are established.

The case of CEDIC and the project "Participatory approach with ethnic focus for Community Development of the Maskoy Diez Leguas ethnicity in the Central Chaco of Paraguay".

The methodology was as follows:

\subsection{Step 1 - Description of the Stakeholders and the Perception of the Problem}

The "Maskoy" indigenous ethnicity which inhabits the Paraguayan territory is extremely knowledgeable about medicinal plants, but the extreme drought conditions and lack of water, do not allow them to grow food and stimulate the production of medicinal plants, which are currently extinct. They are confined to their land and surrounded by mechanized farming which makes the conservation of their original forest an urgent issue[13].

The Maskoy ethnicity, called themselves Angaité and Guarani speakers, mostly lives in utter poverty and relies almost exclusively on State or NGO's aid. The Maskoy came to this land 27 years ago as a result of a donation of 4,090 hectares by the tannin company Casado, which moved them to these places from Puerto Casado in Alto Paraguay. They are originally hunter and gatherer groups, so that the transience of their homes and little or almost no food production characterize their settlements, currently in famine situation.

Illiteracy and lack of a specific trade cause the lack of economic production for the families, bringing severe malnutrition problems, lack of family food production and poor sanitation. Food is the main need, they do not have vegetable gardens and very few produce a subsistence crop. The area is endemic for Chagas disease and historical levels of infestation of the houses were around $30 \%$. Currently, the infestation is low but as they do not maintain a vector surveillance system re-infestation of the houses is imminent [14] [15].

\subsection{Step 2 - The Relationship with Stakeholders and Participatory Approach to Deepen the Problem}

The relationship with the indigenous families from the community of Diez Leguas was from the Chagas National Program of the Ministry of Health and Welfare that installed an entomological surveillance system to prevent early re-infestations in the houses of these people.

Six community workshops were conducted with ethnic and participatory approach to achieve the desired objectives: the improvement and ordering of the indigenous housing. During these workshops, information about other needs and problems was also collected such as lack of access to existing services (safe water and food), unemployment and under-employment, confirming the lack of trades and training, malnutrition caused by the dismantling of the food production system and the destruction of the survival means, among others.

\subsection{Step 3 - Preparation of the Proposal (project) and Involvement of the Research Community - the Quadruple Helix}

- The users/citizens, as the center and focus: the Maskoy ethnicity, from which needs were gathered and problems were validated in participatory workshops

- The researchers/academia, as generators of knowledge and solutions: The CEDIC, a non-profit center, with eight researchers from various areas of science: health area (epidemiology, molecular eco-epidemiology), 
engineering and technologies area (civil engineering, environmental, agricultural and chemical) social area (human ecology, anthropology, business and social innovation) and the Career of Graphic Design from the American University.

- The company/funding: The Company Temha (building of ceramic filters and the Yambui Irrigation System), the Sanofi - Aventis Foundation with funding.

- The government/municipality, as facilitators and collaborators: The Ministry of Public Health and Social Welfare with its National Program of Chagas Disease Control, the Municipality of Teniente Irala Fernández with the procurement of materials and supplies for building and means for mobilization.

This conformation and linking of the four sectors position CEDIC as a Living -Lab for the treatment and solution of a real problem from the citizens/users.

\subsection{Step 4 - The Research-Action}

The project proposed training to groups of women and men of the villages in the building of houses by selfmanagement as well as the use of basic technology for collecting water and production of basic food. In all cases, the self-management of the villages was agreed with the indigenous community.

For the house model of self-management, the community was trained in building techniques of soil-cement blocks and in the building process by the researchers, who transferred the building techniques and evaluation of finishes. Simultaneously, a research line on additives was opened that could replace cement in order to use ecological blocks in the building and reduce costs. For this, the incorporation of students who were elaborating their theses was proposed to the academia to incorporate the subject.

For the organic vegetable garden of self-consumption food, an appropriate technology for irrigation, called "Yambui irrigation system", was transferred as well as the introduction of bacteriological ceramic filters for safe water consumption as well as awareness-raising and education actions on the water care and management. As in the previous section, this irrigation system opened other study areas on plant physiology and pores sizes of the ceramics that were incorporated into the subjects of the students' theses in the academia to improve the performance of ceramics.

To use school as a gateway to health education and disseminate the contribution of graphic design to social problems and get the academy close to potential investors and society, CEDIC and the School of Graphic Design of the American University initiated a joint venture with the aim of promoting the creation of a series of educational materials related to Chagas disease with students of the subject Proyect 3 (2013) of the seventh semester. This was aimed at children between 7 and 12 years old of the schools of the Chaco to initiate health education in the primary period on one of the most prevalent diseases in the area.
Schematizing the model:

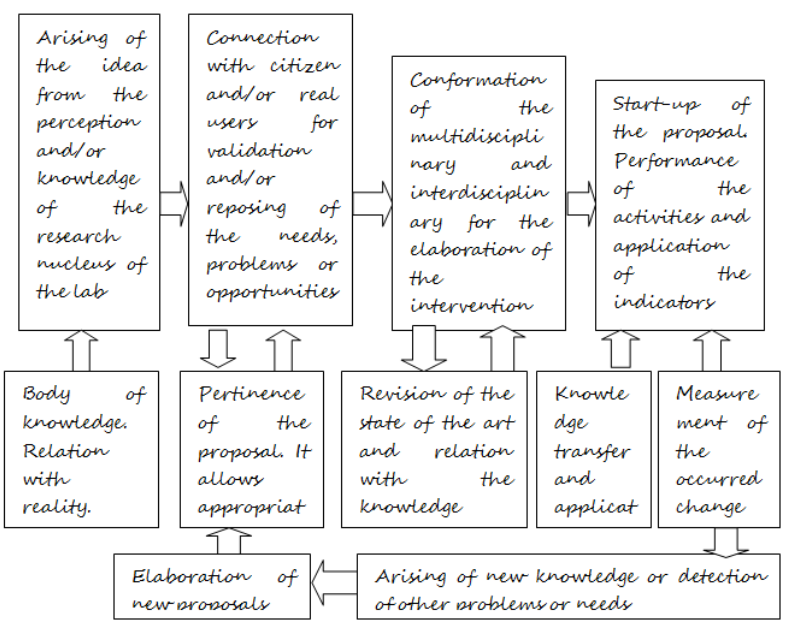

\section{Results}

Below are the results achieved from the research-action performed within the framework of the project developed by CEDIC and the stakeholders and institutions "Participatory approach with ethnic focus for Community Development of Maskoy Diez Leguas ethnicity in the Central Chaco of Paraguay".

\subsection{Collection of Water and Organic Vegetable Gardens for Production of Basic Food}

To make possible the collection of rainwater, zinc roofs with gutters that collect water in tanks were implemented. This was the option chosen by the community, but they also experienced other modalities such as collection tents and access to safe water for human consumption through locally made ceramic filters. Two (2) bacteriological ceramic filters developed by the Company Temha were installed, one in the Health Post and the other in the Primary School of the "12 de Junio" village. A workshop was conducted for the delivery of these filter units, addressed to all interested people in the community, presenting the technology and developing awarenessraising and education activities about water care.

Twelve indigenous women of this village were trained in community vegetable gardens for places of extreme drought, using clay pots called "Yambui", which function as an irrigation system with ability to reduce evapotranspiration by $60-80 \%$. The vessels were built by the women and a follow-up was made for five (5) months, during which the knowledge to obtain food products was strengthened.

\subsection{Housing Model}

In the "12 de Junio" village, a model house was built with walls and roofs that help to eliminate access points for the transmitting vector of Chagas disease, in addition to using the roofs as water collectors for the drought season. 
The blocks were built with a manual machine for cementsoil. The building was finally used as a health post in the village, on the initiative and request of the indigenous community itself.

In the Karandillas1 village, where there is no water, an agreement was established with another ethnicity, the "Nivaclé de Casuarina" indigenous community, which had manual blockers for manufacturing bricks. The indigenous people of Karandillas were trained in the use of the machines and made the necessary blocks for their house model and built the foundation, walls and floor under supervision and permanent training. Currently, the local community decided to use the building as a primary school. At the same time, a small school was improved for the collection, storage and use of rainwater in the "Diez leguas centro" community.

\subsection{Health Education}

A total of 18 proposals about recreational games and tales were developed by the students of Graphic Design after a previous research on Chagas disease. These games were later validated in schools of the Chaco.

The National Program for Chagas Disease Control has recently proposed the printing of four of these games for distribution within the framework of its surveillance program in schools during the Week of Chagas. The initiative demonstrates the importance and complementarity of interdisciplines, which strengthen the expertise to promote communication of environmental health issues in the process of prevention and control in a society devoid of information on these topics.

\section{Conclusion}

From the real stakeholders (the Maskoy Diez Leguas ethnicity in the Central Chaco of Paraguay), and following the perspective of the Stakeholder Theory and the Soft Systems Methodology (SSM) according to Peter Checkland [12], the experience was successful as the "ethnic focus" could be applied, allowing greater involvement and ownership of technologies and skills transferred by the researchers of CEDIC enabling the conjunction of the quadruple helix or "sectors" making it a living lab pilot.

This conjunction allowed the open and social innovation in the community Angaité of Diez Leguas, where people learn the technology to achieve the required products and observe the results, and has brought significant improvements.

Since this intervention on the application of new knowledge and obtainment of products, the community has achieved the:

- Building of a house model with soil-cement blocks

\footnotetext{
${ }^{1}$ Karandillas or Karantillas is the name of one of the villages intervened in this project, located in the Department of Presidente Hayes (Paraguay). It does not have either drinkable water or school. The children attend the school of a close village, called Palo Blanco, and they also go to this village to get water daily.
}

and training to replicate it,

- Training in building for installation of tanks and gutters, and testing of new ideas for water collection,

- Building of organic vegetable gardens for areas of high water stress, and

- Use and training of ceramic filters for safe water consumption.

With the model applied in the "Participatory Approach with ethnic focus for Community Development of the Maskoy Diez Leguas ethnicity in the Central Chaco of Paraguay", it has been confirmed that "Living Labs" are ideal spaces for open innovation and technology transfer as well as the results of the research and an alternative for the proposal of solutions to various social problems. It also confirmed that the development of the conditions mentioned by Katzy, Baltes and Gard [3]: courage, openness, realism, influence and sustainability reduce investment risks in the development of new products, as they work as "intermediaries" in the acceptance of the new by the users and co-owners, in our case: the Maskoy ethnicity.

\section{References}

[1] Macías-Chapula C. Diseño de un modelo conceptual sobre la transferencia de resultados de investigación en salud pública en Honduras. (Spanish). Salud Pública De México [serial online]. December 2012;54(6):624-631. Available from: MedicLatina, Ipswich, MA. Accessed August 27, 2013.

[2] Ståhlbröst, A. A set of key principles to assess the impact of Living Labs. International Journal Of Product Development, 17(1/2), 60-75, 2012.

[3] Katzy, B. R., Baltes, G. H., \& Gard, J. Concurrent process coordination of new product development by Living Labs an exploratory case study. International Journal Of Product Development, 17(1/2), 23-42, 2012.

[4] Guzman, J., del Carpió, A., Colomo-Palacios, R., \& Velasco de Diego, M. Living Labs for User-Driven Innovation. Research Technology Management,56(3), 29-39. doi:10.5437/08956308X5603087, 2013.

[5] Galaso, JA. Metodología de innovación con ciudadanos por el CitiLab de Cornellà. Revista CTS, $n^{\circ} 23$, vol. 8, 249-258, 2013.

[6] Proenza F, Bastidas, R y Montero, G. Telecentros para el desarrollo socioeconómico y rural en América Latina y el Caribe. Oportunidades de inversión y recomendaciones de diseño con especial referencia a Centroamérica. Disponible en http://www.iadb.org/regions/telecentros/index.htm., 2011.

[7] Rutherford, J. Ventanas al mundo de la ciencia: preparación y oportunidad. Revista CTS, no 1 vol. 1 (pág. 197-208), Septiembre de 2003

[8] Stichweh, R. History of Scientific disciplines 2001, en "International Encyclopedia of the Social and Behavioral Sciences, Elsevier, 2001, pags 13727 - 13731 
[9] Stichweh, R. Multiple Publics of science: Inclusion and Popularization, 2003

[10] Pérez C., M. de M. Aproximación a un estudio sobre vulnerabilidad y violencia familiar, Boletín Mexicano de derecho comparado, no. 113, México, pp., 845 - 867, 2005.

[11] Organización de las Naciones Unidas, (2010). Departamento de Información Pública. DPI/2551/A, 0964061. Recuperado el 26 de agosto de 2013: http://www.un.org/esa/socdev/unpfii/documents/SOWIP_fac t_sheets_ES.pdf.

[12] Checkland P. Autobiographical retrospectives: Learning your way to 'action to improve' - the development of soft systems thinking and soft systems methodology. International Journal Of General Systems [serial online]. July 2011;40(5):487-512. Available from: Academic Search Premier, Ipswich, MA. Accessed August 27, 2013.
[13] Rojas de Arias A. Ecosistema y Salud. El impacto de las alteraciones ambientales en las enfermedades transmitidas por vectores. En: Biodiversidad del Paraguay. Una aproximación a sus realidades. D. Salas Dueñas \& JF Facetti Edts. 1ra ed. Fundación Moisés Bertoni, USAID/GEF/BM. 57-76 pp., 2007.

[14] Rojas de Arias A. Control y Vigilancia de Chagas con la participación comunitaria de etnias indígenas: Una perspectiva de la situación. XIIa. Reunión Intergubernamental INCOSUR/Chagas，120'124 Santiago, Chile, 2003.

[15] Rolón M., Vega MC, Román F, Gómez A, Rojas de Arias A. First report of colonies of sylvatic T. infestans (Hemiptera: Reduviidae) in the Paraguayan Chaco, using a trained dog. PLoS Negl Trop Dis 5(5): e1026. doi:10.1371/journal.pntd.0001026., 2011. 